\title{
KEKUATAN SURAT BUKTI PERKAWINAN YANG DILANGSUNGKAN DI LUAR INDONESIA SETELAH DIDAFTARKAN DI KANTOR CATATAN SIPIL
}

\author{
Oleh : \\ Isetyowati Andayani
}

\begin{abstract}
Strength of bill of evidence of marriage which is passed off outside indonesia have the perfect legal force, that matter as according to appliance of letter evidence representing one of pembukti in scope of relationto court of justice. indonesia

In the case of happened the divorce can be brought to trial country in region in
\end{abstract}

Keyword : Letter Strength, Marriage Evidence Of Outside Indonesia

\section{PENDAHULUAN}

Dalam suatu kehidupan yang sudah menjadi kodrati, bahwa manusia diciptakan untuk saling berhubungan. Manusia saling membutuhkan perlindungan, ketenangan, ketenteraman dan kedamaian.

Manusia dalam menunjang kelangsungan hidupnya dibutuhkan adanya suatu hubungan hidup antara seorang pria dengan seorang wanita yang diwujudkan dalam suatu ikatan perkawinan yang sah.

Terjadinya ikatan perkawinan yang sah ini akan terbentuknya suatu keluarga yang nantinya dapat mewujudkan kelangsungan kehidupan manusia. Suatu keluarga merupakan satu kesatuan yang terdiri dari suami, isteri dan anak-anaknya (kalau ada anak) yang merupakan sendi kelangsungan kehidupan dalam masyarakat Indonesia.

Dalam mewujudkan ikatan perkawinan yang sah diperlukan adanya aturan-aturan yang dibuat oleh peme-rintah Indonesia, agar mewujudkan ke-hidupan yang kekal dan tenteram, bahagia yang didambakan oleh semua manusia di dunia, khususnya manusia (keluarga) Indonesia. Kesejahteraan dan ke-bahagiaan hidup bersama dalam ikatan keluarga yang sah menentukan kesejahteraan dan kebahagiaan masyarakat dan Negara Indonesia.

Untuk melangsungkan suatu perkawinan harus memenuhi syarat- 
syarat yang ditentukan oleh peraturan perundang-undangan Indonesia. Salah satu peraturan yang mengatur tentang Perkawinan adalah Undang-Undang Perkawinan Nomor 1 Tahun 1974 (selanjutnya UU No. I Tahun 1974), yang peraturan pelaksanaannya salah satunya yaitu Peraturan Pemerintah No. 9 Tahun 1975. Dalam pasal 1 UU No. I Tahun 1974 mendefinisikan perkawinan yang didalamnya ada tujuan perkawinan. Dalam bukunya Soedharyo : Tata Tertib dan Kaidah-Kaidah ini pula yang telah dirumuskan dalam suatu undang-undang yang disebut Undang-Undang Pokok Perkawinan. Dalam pasal 1 berbunyi : Perkawinan ialah ikatan lahir bathin antara seorang pria dengan seorang wanita sebagai suami isteri dengan tujuan membentuk keluarga (rumah tangga) yang bahagia dan kekal berdasarkan Ketuhanan Yang Maha Esa (Soedharyo Soeimin, 1992 : 4).

Dari definisi perkawinan tersebut tersirat adanya unsur keagamaan yaitu kehidupan yang kekal berdasarkan Ketuhanan Yang Maha Esa, hal ini mendasari dan meletakkan perkawinan sebagai ikatan suami isteri yang suci sesuai dengan ajaran agama masing- masing, karena lembaga perkawinan sebagai lembaga yang sakral. Syarat sahnya perkawinan pun menjunjung tinggi unsure keagamaan, yaitu bahwa perkawinan sah, apabila dilakukan menurut hukum masing-masing agamanya dan kepercayaannya itu, dan tiap-tiap perkawinan dicatat menurut peraturan perundang-undangan yang berlaku (Vide Pasal 2 ayat (2) UU No. I Tahun 1974).

Dalam mewujudkan kesejahteraan masyarakat, sangat penting artinya kesejahteraan dan kebahagiaan keluarga. Karena tidak dapat lain, masyarakat yang berbahagia akan terdiri atas keluargakeluarga yang berbahagia pula. Untuk dapat mencapai hal ini, maka diharapkan kekekalan dalam perkawinan, yaitu bahwa sekali orang melakukan perkawinan, tidak akan bercerai untuk selama-lamanya, kecuali cerai karena kematian (R. Soetojo Prawirohamidjojo, $1986: 42$ ).

Mengenai pembentukan suatu keluarga yang didahului dengan suatu ikatan perkawinan, maka dipandang perlu adanya suatu pengetahuan yang berkaitan dengan pelaksanaan suatu perkawinan. Seseorang yang akan melangsungkan perkawinan dengan pihak lain atau calon suami-isteri yang akan 
melangsungkan perkawinan, harus memenuhi syarat intern dan syarat ekstern yang telah diatur oleh peraturan perundang-undangan kita.

Dalam suatu perkawinan apabila syarat-syarat yang diharuskan telah dipenuhi, maka dapat dilangsungkanlah suatu perkawinan antara seorang pria dengan seorang wanita. Namun apabila persyaratan pelangsungan suatu perkawinan tidak dipenuhi maka suatu perkawinan sulit untuk terwujud.

Dalam perkembangan pergaulan kehidupan dimungkinkan adanya hubungan antara seorang pria dengan seorang wanita yang berbeda agama ingin melangsungkan perkawinan.

Namun sekitar tahun 1990-an oleh Kantor Catatan Sipil (KCS) tidak diakomodasi yaitu tidak dibuatkan suatu tanda bukti, hal ini ada suatu alasan dari catatan sipil, takut melanggar pasal 2 UU No. I Tahun 1974, yaitu melanggar agama. Jadi harus ada upacara keagamaan dulu baru dicatatkan di hadapan Pegawai Pencatat Perkawinan. Sehingga dari kendala terhadap perkawinan antar agama tersebut ada yang berupaya untuk melangsungkannya di luar negeri. Hal ini dilakukan semata untuk mewujudkan cinta kasih diantara mereka. Sedangkan mengenai perkawinan antar agama dalam UU No. I Tahun 1974 tidak di atur, yang di atur mengenai perkawinan antar warga Negara yang salah satunya adalah warga Negara Indonesia.

Apabila perkawinan antar agama tersebut dilangsungkan di luar negeri, maka hal ini termasuk lingkup Hukum Perdata Internasional, sehingga perlu ada pengkajian oleh aturan Hukum Perdata Internasional. Van Brakel dalam bukunya "Grand Slagen en Beginselen van Netherlands Internationaal Privaatrecht' mengatakan "Internationaal privaatrecht is national recht voor international rechts verhoudingen geschreven" (Hukum Perdata Internasional adalah hukum nasional yang ditulis (diadakan) untuk hubungan-hubungan hukum Internasional) (Sunaryati Hartono, 1989 : 8). sedangkan bagi negara-negara Indonesia yang melangsungkan per-kawinan diluar negeri, maka diperlukan pengetahuan hukum yang mengatur tentang perkawinan yang dilangsungkan diluar negeri. Dari hal tersebut di atas akan dibahas mengenai permasalahan sebagai berikut : 
1) Bagaimanakah pengaturan perkawinan yang dilangsungkan di luar Indonesia?

2) Bagaimanakah kekuatan Surat Bukti Perkawinan yang dilangsungkan di luar Indonesia setelah di daftarkan di Kantor Catatan sipil?

\section{Tinjauan Perkawinan Antar Agama}

Perwujudan pelangsungan kehidupan manusia, salah satunya melalui suatu perkawinan yang sah. Untuk sahnya perkawinan sudah ditentukan dalam pasal 2 UU No. I Tahun 1974. Namun hingga saat ini yang masih adanya ketidakpastian apabila terjadi perkawinan antar agama. Di satu sisi antara calon suami dan isteri sudah saling menyintai dan mengasihi, namun karena kendala adanya perbedaan agama maka sulitlah mereka melangsungkan perkawinan, catatan sipil tidak bersedia mencatat apabila upacara keagamaan yang sesuai dengan pasal 2 ayat (1) UU No. I Tahun 1974 belum dilangsungkan. Sehingga bagi mereka yang mempunyai dana (uang) berupaya untuk tetap melangsungkan perkawinannya di luar Indonesia. Tetapi bagi mereka yang tidak mempunyai dana, sulit untuk mewujudkan perkawinannya. Sehingga ada upaya untuk sementara tunduk pada salah satu agama yang lainnya agar mendapat alat bukti perkawinan sesuai dari kewenangan lembaga yang mengeluarkan bukti tersebut. Bagi yang beragama Islam oleh Kantor Urusan Agama (KUA), bagi yang selain Islam oleh Kantor Catatan Sipil (KCS).

Perkawinan antar agama sebenarnya merupakan salah satu bentuk perkawinan campuran. Sedangkan UU No. I Tahun 1974, perkawinan campuran yang di atur hanya antara Warga Negara Indonesia (WNI) dan Warga Negara Asing (WNA). Sehingga perkawinan antar agama tidak di atur dalam UU No. I Tahun 1974. Tetapi perlu di ingat sebelum di undangkannya UU No. I Tahun 1974, perkawinan campuran itu di atur dengan Koninklijk Besluit tanggal 29 Desember 1896 No. 23. Peraturan ini disebut Regeling op de Gemengde Huwelijken, dengan singkatan G.H.R. yang sekarang biasa disebut dengan istilah Peraturan Perkawinan Campuran (R. Soetojo Prawirohamidjojo, 1988 : 89).

Arti perkawinan campuran menurut bunyi pasal 1 G.H.R adalah Perkawinan antara orang-orang yang di 
Indonesia tunduk pada hukum yang berlainan.

Definisi ini sangat luas jangkauannya, tidak membatasi arti perkawinan campuran pada perkawinan-perkawinan antar WNI atau antar penduduk Indonesia (antara orang-orang) dan perkawinanperkawinan yang dilangsungkan di Indonesia, asalkan pihak-pihak yang melangsungkan perkawinan di Indonesia "tunduk pada hukum yang berlainan" adalah "perkawinan campuran".

Sedangkan perkawinan campuran dalam undang-undang ini ialah perkawinan antara dua orang yang di Indonesia tunduk pada hukum yang berlainan, karena perbedaan kewarganegaraan, dan salah satu pihak berkewarga-negaraan Indonesia.

Dari rumusan tersebut di atas, perumusan tentang perkawinan campuran yang tercantum dalam pasal 57 UU No. I Tahun 1974lebih sempit daripada perumusan dalam ketentuan pasal 1 Regeling op de Gemengde Huwelijken, oleh karena pasal 57 hanya menjangkau perkawinan antara WNI dengan WNA atau perkawinan Internasional.

Sedangkan perkawinan antar agama tidak terjangkau. Bila kita periksa interpretasi otentik mengenai istilah perkawinan campuran sesuai dengan pembentuk undang-undang, dapat dikemukakan pada pasal 1 G.H.R dan dianggap sebagai suatu ulangan dari apa yang sudah dirumuskan dalam konsiderannya, yaitu "Huwelijken tussen personen die in Indonesie aan een verschillend recht onderworpen zijn, worden gemengde huwelijken genoemd" (Perkawinan antara orang-orang yang di Indonesia tunduk pada hukum yang berlainan disebut perkawinan campuran) ( $R$. Soetojo Prawirohamidjojo, 1988 : 92).

Mengenai perkawinan antar agama seharusnya bisa dilangsungkan di Indonesia dengan landasan pada penafsiran a contrario terhadap pasal 66 UU No. I Tahun 1974. penafsiran a contrario (menurut pengingkaran) ialah suatu cara penafsiran undang-undang yang didasarkan pada perlawanan pengertian antara soal yang dihadapi dan soal yang diatur dalam suatu pasal undang-undang (CST. Kansil, 1989: 69).

Sehingga melalui pasal 66 UU No. I Tahun 1974, mengenai perkawinan antar agama masih dapat menerapkan pasal 1 G.H.R. Memberlakukan peraturan lama sesuai dengan penjelasan umum ad. 5 
Tambahan Lembaran Negara RI No. 3019 yang berbunyi "Untuk menjamin kepastian hukum, maka perkawinan, berikut segala sesuatu yang ber-hubungan dengan perkawinan, sebelum undang-undang ini, yang dilakukan menurut hukum yang telah ada adalah sah.

Demikian pula apabila mengenai sesuatu hal undang-undang ini tidak mengatur dengan sendirinya berlaku ketentuan yang ada. Disamping itu apabila kita membaca pada Tambahan Lembaran Negara RI No. 3019, pada penjelasan dibawah ad. 3 bagian umum kalimat yang mengatakan "..... di lain pihak, harus dapat pula menampung segala kenyataan yang hidup dalam masyarakat dewasa ini". Dengan demikian perkawinan campuran tidak terbatas pada perkawinan antara $\mathrm{WNI}$ dengan WNA di Indonesia saja, akan tetapi termasuk pula perkawinan campuran antar agama dan kepercayaan.

\section{Lingkup Hukum Perdata Internasional}

Pendapat dari Prof. R.H. Graveson "The Conflict of Laws, or Private International Law, is That Branch of Law Which Deals With Cases in Which Some Relevant Fact Has a Connection With Another System of Law on Either Territorial or Personal Grouns, and May, on That Account, Raise a Question as to the Application of one's Own or The Appropriate Alternative (Usually Foreign) Law to the determination if the Issue, or as to the Exercise of Jurisdiction by one's Own or Foreign Courts" yang terjemahannnya : Hukum Perdata Internasional adalah bidang hukum yang berkenaan dengan perkara-perkara yang didalamnya mengandung fakta relevan yang menunjukkan berkaitan dengan suatu system hukum lain, baik karena aspek teritorial maupun aspek subyek hukumnya, dan karena itu menimbulkan pertanyaan tentang penerapan hukum sendiri atau hukum lain (yang biasanya asing), atau masalah pelaksanaan yurisdiksi badan pengadilan sendiri atau badan pengadilan asing (Graveson, R.H, $1974: 3)$.

Van Brakel dalam bukunya "Grondslagen en Beginselen van Netherlands Internationaal Privaatrecht" berpandangan bahwa "Hukum Perdata Internasional adalah hukum nasional yang 
dibuat untuk hubungan-hubungan hukum Internasional" (Sunaryati Hartono, 1989 : 8).

Sedangkan Sunaryati Hartono perpandangan bahwa Hukum Perdata Internasional mengatur setiap peristiwa/ hubungan hukum yang mengandung unsur asing, baik dibidang hukum public maupun hukum privat. Karena inti dari Hukum Perdata Internasional adalah pergaulan hidup masyarakat internasional, maka Hukum Perdata Internasional sebenarnya dapat disebut sebagai hukum pergaulan internasional. (Sunaryati Hartono, 1989 : 29).

Gouwgioksiong mengatakan, bahwa Hukum Perdata Internasional bukanlah hukum internasional, tetapi hukum nasional. Dan menurut pendapat Schnitzer, "Nicht das Recht sondern der Tatbestand ist International". Jadi Hukum Perdata Internasional, bukan sumber hukumnya internasional, tetapi materinya yaitu hubungan-hubungan atau peristiwa-peristiwa yang merupakan obyeknyalah yang internasional (Sunaryati Hartono, 1989 : 8).

Sudargo Gautama merumuskan Hukum Perdata Internasional sebagai berikut " Keseluruhan peraturan dan keputusan yang menunjukkan stelsel hukum manakah yang berlaku atau apakah yang merupakan hukum, jika hubungan-hubungan dan peristiwaperistiwa antara warga Negara pada satu waktu tertentu memperlihatkan titik-titik pertalian dengan stelsel-stelsel dan kaidah-kaidah hukum dari dua atau lebih Negara, yang berbeda dalam lingkungan kuasa/tempat, (pribadi dan soal-soal . “ Jadi disini yang ditekankan adalah perbedaan dalam lingkungan kuasa tempat dan soal-soal serta pembedaan dalam sistem satu negara dengan lain negara, artinya ada unsur luar negerinya" (Foreign element, unsur asing) (Sudargo Gautama, 1985 : 21).

Dari hal tersebut di atas dapat disimpulkan bahwa Hukum Perdata Internasional merupakan hukum nasional suatu Negara yang mengatur hubunganhubungan antara perseorangan dari berbagai Negara. Sedangkan internasionalnya menunjukkan adanya unsur asing.

Setiap negara memiliki hukum perdata nasional sendiri. Peraturan hukumnya akan berlaku bagi setiap warga Negara, dari Negara masing-masing. Kalau terjadi peristiwa hukum perdata 
yang menyangkut "unsur asing" di dalamnya, maka sifat peraturan hukum itu berubah menjadi internasional dan peristiwa hukum tersebut diselesaikan menurut peraturan hukum perdata yang berlaku di Negara itu. (Siti Suharnani, 2004 : 57). Unsur asing disini, dimaksudkan adalah : 1). person (orangnya) yang warga negara asing, 2). tempatnya menunjukkan di negara asing.

Adapun Peraturan-Peraturan Hukum Perdata Internasional terdiri dari 2 golongan :

a. Peraturan-peraturan petunjuk (Verwijsingsregels: Hukum mana).

b. Peraturan-peraturan asli atau peraturan-peraturan sendiri (Eigenregels : Hukum apa). (A. Siti Soetami, 1992: 89).

Peraturan petunjuk, yaitu peraturan yang menunjuk hukum nasional mana yang akan mengatur hubungan yang bersangkutan. Jadi Hukum Perdata Internasional adalah hukum nasional untuk menyelesaikan perkara internasional.

Peraturan asli, yaitu peraturan yang memberikan penyelesaian sendiri. Peraturan sendiri ini tidak menunjuk pada hukum nasional mana yang akan mengaturnya, tetapi mengatur sendiri.

Peraturan petunjuk yang terdapat dalam Peraturan Perundang-Undangan Indonesia antara lain terdapat di :

1) Pasal 16 Algemene Bepalingen van Wetgeving $(\mathrm{AB})$ mengenai Statuta personil, adanya asas Lex originis tentang status seseorang.

2) Pasal $17 \mathrm{AB}$ : tentang statuta riel adanya asas Lex reisital tentang status benda tidak bergerak.

3) Pasal $18 \mathrm{AB}$ : menerangkan berlakunya statuta Mixta, yaitu bentuk tiap perbuatan (cara menjalankan perbuatan) ditentukan oleh Undangundang Negara atau tempat, dimana perbuatan itu diadakan.

Peraturan asli yaitu peraturan yang memberikan penyelesaian sendiri. Peraturan sendiri ini tidak menunjukkan pada hukum nasional mana yang akan mengaturnya, tetapi mengatur sendiri. Misalnya :

- Traktat Warsawa 12 - 10 - 1929 mengenai pengangkutan udara.

- Pasal 945 Burgerlijk Wetboek (BW) : seorang WNI, yang ada di Negara asing, akan tidak dapat membuat surat wasiat kecuali dengan akta Authentiek dan dengan meng- 
indahkan formalitet yang lazim di Negara tempat dibuatnya akta itu.

- Pasal 83 BW : Perkawinan yang dilakukan di luar negeri, baik antara WNI sendiri maupun antara WNI dan WNA adalah sah, jika dilangsungkan Tetapi pasal 83 BW ini sudah tidak berlaku dengan dikeluarkannya UU Perkawinan No. I Tahun 2009.

- Pasal 56 UU No. I Tahun 1974, tentang perkawinan di luar neger (Luar Indonesia).

- Pasal 57 UU No. I Tahun 1974 tentang perkawinan campuran (Perkawinan antara WNI dengan WNA).

Disamping kemungkinan menggunakan peraturan petunjuk dan peraturan asli, ada kemungkinan ketiga yaitu kedua belah pihak mengadakan pilihan hukum.(Rechts kueze) yaitu mereka setuju bahwa hubungan mereka akan di atur oleh hukum yang dipilinnya sendiri. Misalnya seorang pedagang warga negara Belgia dan seorang pedagang warga negara Perancis mengadakan persetujuan jual beli yang atas pilihan mereka, memilih diatur oleh hukum Belanda (A. Siti Soetami, 1992: 91).
Dalam Hukum Perdata Internasional, selain ketentuan-ketentuan petunjuk, ketentuan asli (mandiri) dan pilihan hukum ada juga kaidah-kaidah HukumPerdata Internasional. Kaidahkaidah tersebut dapat diterapkan apabila dalam menghadapi persoalan Hukum Perdata Internasional tidak terlandasi pada ketentuan petunjuk dan ketentuan mandiri, dan hubungan hukum para pihak tidak melakukan pilihan hukum. Ada beberapa kaidah-kaidah Hukum Perdata Internasional (HPI) (tidak disebutkan semua) antara lain : Titik Taut, Kualifikasi, Ketertiban Umum, Pilihan Hukum, Penyelundupan Hukum, Hak-Hak Yang Diperoleh, Persoalan Pendahuluan, dan sebagainya.

Tentang Titik Taut : adanya kemungkinan suatu kaidah hukum asing yang berlaku bagi suatu peristiwa hukum karena adanya unsur asing. Sedangkan Titik Taut membantu kita untuk mengetahui bahwa hubungan hukum tersebut merupakan lingkup hukum perdata internasional. Macam-macam Titik Taut, yaitu:

\section{1). Titik Taut Primer,}

2). Titik Taut Sekunder. 
Titik Taut Primer dinamakan Titik Taut Pembeda, yaitu unsur-unsur yang menunjukkan bahwa suatu peristiwa hukum merupakan peristiwa HPI. Misalnya : a). WNI menikah dengan WNA (Amerika), disini WNA (Amerika) menunjukkan peristiwa HPI., b). Dua WNI menikah di Australia karena dilangsungkan di Australia (Locus celebrationis asing). Australia menunjukkan peistiwa HPI.

Titik Taut Sekunder dinamakan Titik Taut Penentu. Akan menentukan "Hukum Manakah" yang harus berlaku bagi peristiwa HPI. Misalnya : Menurut perjanjian internasional (Traktat Den Hag). Syarat-syarat untuk melangsungkan perkawinan campuran ditentukan oleh Hukum Nasional Suami-Isteri. Hukum Nasional Suami, Hukum Nasional Isteri menentukan syarat-syarat formil untuk melangsungkan perkawinan.

Kualifikasi sebenarnya adalah melakukan "translation" atau "penyalinan" daripada fakta-fakta sehari-hari dalam istilah-istilah hukum. Fakta-fakta itu dimasukkan dalam kotak-kotak hukum, kelas-kelas, ruang-ruang atau kamarkamar atau bagian-bagian hukum yang sudah tersedia. Ini yang dinamakan klasifikasi dari fakta-fakta Classification of Facts) (Soedargo Gautama, 1985, h,118).

Tentang ketertiban Umum (Soedargo Gautama, 1985 : 133) Ketertiban Umum dalam bahasa Belanda Openbare orde. Ketertiban Umum penting dalam HPI, karena lembaga ketertiban umum ini sangkut paut yang erat dengan paham-paham asasi dan dasar HPI. Jika HPI kita telah menentukan bahwa hukum asing harus diperlakukan, Hal ini " tidak " berarti bahwa selalu dan dalam semua hal harus dipergunakan hukum asing tersebut. Jika pemakaian dari hukum asing berarti suatu pelanggaran yang sangat daripada sendi-sendi asasi hukum nasional hakim, maka dalam hal "pengecualian", maka dalam hal "Pengecualian", hakim dapat menyampingkan hukum asing ini. Tetapi penerapan Ketertiban Umum harus seminim mungkin, maksudnya jangan mudah selalu menerapkan penerapan Ketertiban Umum, karena dapat mengakibatkan lingkup HPI tidak dapat berkembang dengan baik, karena selalu menerapkan Hukum Nasional, sedangkan hukum Negara lain selalu tidak dipergunakan. Hal ini mempersempit 
pergaulan dunia di era globalisasi.

Pemilihan Hukum (Inggris : Choise of Law; Belanda : Recht keuze). Pemilihan Hukum dapat dilakukan oleh para pihak yang melakukan hubungan hukum. Pilihan Hukum tetap ada batasannya, jadi tidak sebebasbebasnya. Misal : tidak boleh melanggar Ketertiban umum, atau melakukan penyelundupan hukum. Para pihak hanya bebas untuk memilih, tetapi tidak bebas untuk menentukan sendiri perundangundangan.

Penyelundupan hukum dipakai, apabila hukum asing dipakai untuk tujuan melakukan penyelundupan hukum, agar suatu keinginan bisa terwujud, maka hukum asing tersebut tidak boleh dipakai, dan kembali pada hukum nasional dari pihak yang melakukan hubungan hukum. Dalam penyelundupan hukum bahwa hukum nasional tetap berlaku itu dan di anggap tepat pada suatu peristiwa tertentu saja, yang maksudnya : Apabila ada seorang yang untuk mendapatkan berlakunya hukum asing telah melakukan suatu tindakan yang bersifat menghindarkan pemakaian hukum nasional, maka hal ini tidak diperbolehkan karena tujuannya menghindarkan hukum yang seharusnya berlaku.

Hak-Hak yang Telah Diperoleh (HHD), dalam hukum perdata internasional "Hak-hak yang diperoleh dipakai untuk mengedepankan bahea perubahan dari fakta-fakta, tidak akan mempengaruhi berlakunya kaidah yang semula dipakai. Missal : Antara A dan B melangsungkan perkawinan di Negara $X$, dan perkawinan mereka sah menurut Negara $X$, kemudian Dia kembali di negaranya yaitu $Y$ maka seharusnya Negara $Y$ bisa menerima sahnya perkawinan tersebut di negaranya (Negara Y). Van Brakel menganggap bahwa hak-hak yang telah diperoleh di luar negeri sedapat mungkin "harus diakui dan di hormati" merupakan salah satu asas pikiran fundamentil di atas mana sistim HPI di bangun. Tanpa adanya pengakuan daripada asas ini, lalu lintas internasional akan menjadi tidak mungkin (Soedargo Gautama, 1985 : 212). Bahwa prinsip "Hak-hak yang telah diperoleh" dapat dipergunakan untuk memperbaiki atau memperlembut pelaksanaan prinsip Ketertiban Umum. Tentang hak-hak yang diperoleh mengingatkan kita dengan pendapat Ulrik Huber terhadap Teori Statuta di Belanda:

- Setiap Negara memiliki kedaulatan 
sehingga Negara memiliki kewenangan penuh untuk menetapkan kaidah-kaidah HPInya, tetapi

- Dalam kenyataannya, Negaranegara itu tidak dapat bertindak secara bebas, dalam arti bahwa berdasarkan asas Comitas gentium (sopan santun) Negara itu harus mengakui pelaksanaan suatu hak yang telah diperoleh "secara sah" di Negara lain.

Dalam penulisan ini sebagian kaidah-kaidah HPI yang diambil / yang berkaitan dengan perkawinan yang dilangsungkan di luar Indonesia bagi WNI.

\section{Pengaturan Perkawinan yang Dilangsungkan di Luar Indonesia}

Seorang pria dengan seorang wanita yang ingin mewujudkan suatu keluarga yang bahagia, maka akan dilangsungkan melalui ikatan perkawinan yang sah. Namun apabila dalam pelangsungan perkawinan ada kendala, misalnya adanya perbedaan agama. Bagi mereka yang mempunyai dana (uang), maka mereka dapat berpikir melangsungkan perkawinan di luar
Indonesia. Ada juga yang tidak berbeda agama, namun berbeda kewarganegaraan, namun ingin melangsungkan perkawinan di luar Indonesia, yaitu di negara calon pasangan perkawinannya.

Jadi disini akan terjadi perkawinan :

- WNI dengan WNI.

- WNI dengan WNA.

Yang perkawinannya dilangsungkan di luar Indonesia. Mengenai hal tersebut maka perkawinan yang mereka lakukan termasuk lingkupnya $\mathrm{HPI}$, hal ini disebabkan karena adanya unsur asing yaitu :

- Tempat dilangsungkannya perkawinan (Negara asing) (WNI XWNI).

- Orangnya menunjukkan unsur asing dan dilangsungkan di Negara asing ( WNIXWNA).

Karena merupakan lingkup HPI maka akan dikaitkan dengan ketentuanketentuan, dan mungkin juga kaidah HPI.

Berdasarkan ketentuan HPI yaitu peraturan yang asli atau mandiri, maka pengaturan tentang perkawinan di luar Indonesia ada dalam pasal 56 UU No. I Tahun 1974 ayat : 
(1). Perkawinan yang dilangsungkan diluar Indonesia antara dua orang WNI atau seorang WNI dengan WNA adalah sah bilamana dilaku-kan menurut hukum yang berlaku di Negara dimana perkawinan itu dilangsungkan dan bagi WNI tidak melanggar ketentuan-ketentuan UU No. I Tahun 1974.

(2). Dalam waktu 1 (satu) tahun setelah suami isteri itu kembali di wilayah Indonesia, surat bukti perkawinan mereka harus didaftarkan di Kantor Pencatatan Perkawinan tempat tinggal mereka.

Bahwa ternyata pengaturan tentang perkawinan di luar Indonesia hanya satu (1) pasal dua (2) ayat saja, sedangkan kalau dicari dalam penjelasannya, tertulis cukup jelas. Dari hal tersebut akan menimbulkan multi penafsiran. Seperti halnya terhadap kalimat (pasal 56 ayat (1)) ..... adalah sah bilamana "dilakukan menurut hukum" yang berlaku di Negara dimana perkawinan itu dilangsungkan ....... Dari kalimat tersebut tidak jelas apakah memenuhi hukum formilnya atau materiil dari Negara asing tersebut. Selanjutnya dalam pasal 56 ayat (1) dan bagi WNI tidak melanggar ketentuan-ketentuan undang-undang ini (UU No. I Tahun 1974). Dari kalimat tersebut tidak jelas, bagaimana kalau menurut Negara asing tidak melanggar, kemudian menurut hukum Indonesia melanggar, contohnya tentang perkawinan antar agama.

Kemudian bunyi pasal 56 ayat (2) "Dalam waktu 1 (satu) tahun ........ kembali di wilayah Indonesia surat bukti perkawinan mereka harus didaftarkan di Kantor Pencatatan Perkawinan mereka. Hal ini menimbulkan pertanyaan bagaimana kalau melebihi jangka waktu 1 tahun. Dan apakah Kantor Pencatatan Perkawinan hanya mencatat saja, atau membuatkan bukti baru produk Pemerintah Indonesia, hal ini tidak jelas.

Berkaitan dengan aturan yang hanya satu pasal, maka diperlukan bantuan ilmu pengetahuan tentang kaidah-kaidah HPI karena persoalan tersebut masuk lingkup HPI. Misalnya :

- Tentang kaidah ketertiban umum, yaitu asal Negara asing peraturannya tidak melanggar hak dasar manusia.

- Tentang penyelundupan hukum, asal ke Negara asing tidak bertujuan melakukan penyelundupan hukum. 
- Tentang hak-hak yang diperoleh, lanjut menjadi akta otentik dan akta yaitu apabila hukum Negara asing dibawah tangan (Sudikno Mertokusumo, menganggap sah, maka ber- 1999:121).

dasarkan asas comitas gentium

Akta adalah surat yang diberi tanda (sopan santun bangsa), Negara tangan, yang memuat peristiwa yang (Indonesia) itu harus mengakui menjadi dasar suatu hak atau perikatan, pelaksanaan suatu hak yang telah diperoleh secara sah di Negara lain. Hal ini berlaku sebaliknya.

\section{Tentang Alat Bukti Suatu Surat}

Dalam hubungan keperdataan, terjadinya suatu perkawinan antara seorang pria dengan seorang wanita dengan tujuan membentuk suatu keluarga. Untuk membuktikan adanya suatu perkawinan diperlukan adanya alat bukti yang sah menurut hukum.

Sedangkan alat bukti dalam hukum perdata ada 5 (lima) macam alatalat bukti (Retnowulan Sutanto, 1997 : 61), antara lain : 1). bukti surat; 2). Bukti saksi; 3). Persangkaan; 4). Pengakuan; dan 5). Sumpahan; dan ada tambahan alat bukti yaitu pengetahuan hakim.

Surat sebagai alat bukti tertulis dibagi 2 (dua) yaitu surat yang merupakan akta dan surat-surat lainnya yang bukan akta, sedangkan akta sendiri dibagi lebih yang dibuat sejak semula dengan sengaja untuk pembuktian. Jadi untuk dapat digolongkan dalam pengertian akta maka surat harus ditandatangani (Sudikno Mertokusumo, 1999: 121).

Akta autektik adalah suatu akta yang dalam bentuk yang ditentukan oleh undang-undang, dibuat oleh atau dihadapan pejabat umum yang berkuasa ditempat mana akta itu dibuat (Victor M. Simatupang dan Cormentyna Simatupang, $1991: 54)$.

Akta itu harus dibuat oleh atau dihadapan seorang pejabat umum. Pejabat umum pembuat akta adalah pejabat yang diberi wewenang berdasarkan undang-undang dalam batas wewenang yang telah ditetapkan secara tegas, seperti notaries, panitera, jurasita, hakim, "pegawai catatan sipil", kepala daerah, dll. Suatu akta adalah autektik, bukan karena penetapan undang-undang, akan tetapi karena dibuat oleh atau 
dihadapan seorang pejabat umum (Victor M. Simatupang dan Cormentyna Simatupang, 1991 : 55). Akta dibawah tangan (Onderhands octa) Akta dibawah tangan adalah akta yang sengaja dibuat oleh para pihak untuk pembuktian tanpa bantuan dari seorang pejabat pembuat akta. Berkaitan dengan akta yang dikeluarkan oleh pegawai catatan sipil yang menyangkut akta perkawinan merupakan akta autektik. Karena pegawai catatan sipil yang menandatangani akta perkawinan merupakan pejabat yang diberi wewenang berdasarkan undang-undang.

\section{Kekuatan Surat Bukti Perkawinan Yang Dilangsungkan Di Luar Indonesia}

Dalam pasal 56 ayat (2) UU No. I Tahun 1974 disebutkan : Dalam waktu 1 (satu) tahun ......., surat bukti perkawinan mereka harus di daftarkan di Kantor Pencatatan Perkawinan tempat tinggal mereka.

Dalam tulisan ini yang dimaksud Kantor Pencatatan Perkawinan adalah Kantor Catatan Sipil (KCS).

Lembaga catatan sipil memang penting dalam hubungan keperdataan, sebab catatan sipil dapat menentukan kedudukan hukum seseorang, bagi orangorang yang berkepentingan lembaga ini dapat dengan mudah memperoleh kepastian hukum, mengenai status seseorang. Adanya catatan sipil bertujuan untuk memberikan kepastian hukum sebesar-besarnya mengenai peristiwaperistiwa yang di alami atau terjadi atas diri seseorang, maka semua akta catatan sipil mempunyai kedudukan yang sempurna yang mutlak kebenarannya didepan hukum. Karena produk lembaga catatan sipil merupakan akta autentik maka mempunyai kekuatan pembuktian yang sempurna.

Berkaitan dengan surat bukti perkawinan produk dari luar Indonesia, apakah sama dengan akta autentik produk lembaga catatan sipil Indonesia. Perlu di ketahui bahwa pengertian catatan sipil adalah suatu lembaga yang diadakan oleh penguasa, yang dimaksudkan untuk membukukan selengkap mungkin dan karena itu memberikan kepastian sebesarbesarnya tentang semua peristiwa yang penting bagi status keperdataan seseorang (FX. Suhardana, 1992 : 67). Sehingga fungsi catatan sipil sebagai 
lembaga yang melakukan pencatatan dan pembuatan akta (tanda bukti tertulis) atas peristiwa-peristiwa yang mempunyai arti penting bagi manusia sebagai pendukung hak dan kewajiban dalam lalu lintas hukum (S. Prawirohamidjojo dan Sahoedin, 1982 : 23-24).

Dari fungsi catatan sipil tersebut salah satunya melakukan pencatatan, maka surat bukti perkawinan produk luar Indonesia tersebut hanya dilakukan pencatatan saja sehingga catatan sipil cukup mencatat surat bukti perkawinan tersebut. Perkawinan WNI yang terjadi di luar Indonesia wajib melaporkan perkawinannya ke Dinas Kependudukan dan Catatan Sipil selambat-lambatnya 1 (satu) tahun sejak yang bersangkutan kembali ke Indonesia.

Pelaporan perkawinan sebagaimana yang dimaksud pada ayat (2) pasal 56 UU No. I Tahun 1974 dicatat pada register akta perkawinan dan di terbitkan surat keterangan perkawinan luar negeri.

Adapun persyaratan jika ingin melaporkan perkawinan ke Dinas Kependudukan dan Catatan Sipil adalah :

a) Fotokopi akte perkawinan luar negeri dan terjemahan (adanya suatu lembaga-lembaga yang tersumpah, disini lembaga tersebut yang menerjemahkan dari bahasa asing tersebut).

b) Paspor, Visa kedua belah pihak (suami maupun isteri) sebagai identitas diri.

c) Fotokopi Kartu Tanda Penduduk (KTP), Kartu Keluarga (KK) sebanyak 1 (satu) lembar.

d) Akte Kelahiran (diterjemahkan terlebih dahulu) 1 lembar.

e) Pas photo 4x6 (5 lembar).

f) Membawa keterangan dokumen asli.

g) Mengenai perkawinan WNI di luar negeri yang berkaitan dengan perbedaan agama, pihak catatan sipil tidak pernah mempermasalah-kan, sifat catatan sipil hanyalah tempat pelaporan dan melakukan pencatatan.

Mengenai hal seperti ini seharusnya perbedaan agama tidak harus perkawinannya dilangsungkan di luar Indonesia karena kembali di Indonesia akan dilakukan pencatatan artinya dilakukan pengakuan serta pengesahan oleh catatan sipil sebagai wakil pemerintah Indonesia. 
Sedangkan apabila ditinjau menurut peraturan di Indonesia, melalui pasal 66 UU No, I Tahun 1974, melalui penafsiran a contrario, bisa menunjuk peraturan G.H.R (Tentang perkawinan campuran). Disamping itu biaya atau dana kita tidak lari keluar negeri, cukup dilangsungkan di Indonesia.

Mengenai kekuatan surat bukti perkawinan yang dilangsungkan di luar Indonesia, mempunyai kekuatan bukti yang sempurna. Hal ini sesuai dengan alat bukti surat yang merupakan salah satu pembuktian dalam lingkup hubungan keperdataan.

Sehingga apabila suami isteri yang melangsungkan perkawinan di luar Indonesia, dan kembali ke Indonesia melakukan pelaporan dan dicatat oleh catatan sipil.

Maka apabila ada permasalahan, misalnya mengajukan gugatan cerai maka dapat diajukan ke Pengadilan Negeri di Wilayah Indonesia. Sehingga dikatakan bahwa kekuatan bukti surat perkawinan yang dilangsung-kan di luar Indonesia merupakan suatu akta autentik yang merupakan alat bukti surat yaitu alat bukti yang sempurna dan mempunyai kekuatan hukum yang sempurna pula.

\section{DAFTAR PUSTAKA}

Siti Soetami, Pengantar Tata Hukum Indonesia, PT. Eresco, Bandung, 1992.

CST. Kansil, Pengantar IImu Hukum dan Tata Hukum Indonesia, Cet VIII, Balai Pustaka, Jakarta, 1989.

FX. Suhardana, Hukum Perdata I, Gramedia, Jakarta, 1992.

G.H.S. Lumban Tobing, Peraturan Jabatan Notaris, Erlangga, Jakarta, 1980.

Gravenon, R.H, Conflict of Laws - Private International Law, Sweet and Maxwell, London, $7^{\text {th }}$ edition, 1974.

K. Wantjik Saleh, Hukum Acara Perdata, Chalia Indonesia, Jakarta, 1983.

R. Soetojo Prawirohamidjojo, Pluralisme Dalam Perundang-Undangan Perkawinan di Indonesia, Airlangga University Press, Surabaya, 1986 : 42.

R. Soetojo Prawirohamidjojo, Marthalena 
Pohan, Hukum Orang dan

Keluarga (Personen en

Familie Recht), Airlangga

University Press, Surabaya, 1991.

R. Soetojo Prawirohamidjojo dan Azis

Safioedin, Hukum Orang dan

Keluarga, Alumni, 1986.

Retnowulan Sutantio dan Iskandar Oeripkartawinata, Hukum Acara Perdata dalam Teori dan Praktek, Mandar Maju, Bandung, 1997.

Siti Suharnani, et.al., Buku Ajar Pengantar Hukum Indonesia, Surabaya, Tahun 2004.

Soediharyo Soemin, Hukum Orang dan
Keluarga, Sinar Grafika, Jakarta, $1992: 4$.

Sunaryati Hartono, Pokok-Pokok Hukum Perdata Internasional, Cet III, Bina Cipta, Bandung, 1989.

Sutargo Gautama, Pengantar Hukum Perdata Internasional Indonesia, Binacipta, Cet. III, Bandung, 1985.

Sudikno Mertokusumo, Hukum Acara Perdata Indonesia, Cet. II, Liberty, Yogyakarta, 1999.

Victor M. Situmorang dan Cormentyna Sitanggang, Aspek Hukum Akta Catatan Sipil di Indonesia, Sinar Grafika, Jakarta, 1991. 